
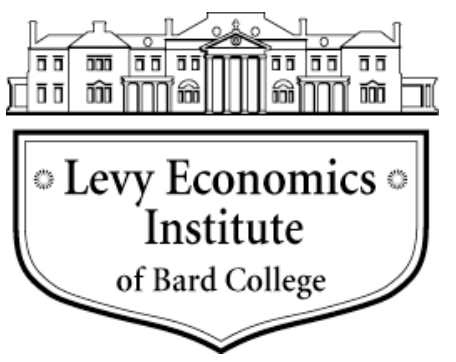

Working Paper No. 702

\title{
The Euro Imbalances and Financial Deregulation: A Post-Keynesian Interpretation of the European Debt Crisis
}

\author{
by \\ Esteban Pérez-Caldentey \\ UN Economic Commission for Latin America and the Caribbean \\ Matías Vernengo* \\ University of Utah
}

January 2012

\begin{abstract}
* The opinions here expressed are the authors' own and may not coincide with that of the institutions with which they are affiliated. A preliminary version of this paper was presented at Universidad Autónoma de México (UNAM) on September 9, 2011, and at the University of Texas at Austin on November 4, 2011. We thank, without implicating them, Jörg Bibow, Heiner Flassbeck, James K. Galbraith, Tom Palley, Carlo Panico, Ignacio Perrotini, and other conference participants for their comments on a preliminary version.
\end{abstract}

The Levy Economics Institute Working Paper Collection presents research in progress by Levy Institute scholars and conference participants. The purpose of the series is to disseminate ideas to and elicit comments from academics and professionals.

Levy Economics Institute of Bard College, founded in 1986, is a nonprofit, nonpartisan, independently funded research organization devoted to public service. Through scholarship and economic research it generates viable, effective public policy responses to important economic problems that profoundly affect the quality of life in the United States and abroad.

Levy Economics Institute

P.O. Box 5000

Annandale-on-Hudson, NY 12504-5000

http://www.levyinstitute.org

Copyright (C) Levy Economics Institute 2012 All rights reserved 


\begin{abstract}
Conventional wisdom suggests that the European debt crisis, which has thus far led to severe adjustment programs crafted by the European Union and the International Monetary Fund in both Greece and Ireland, was caused by fiscal profligacy on the part of peripheral, or noncore, countries in combination with a welfare state model, and that the role of the common currency - the euro - was at best minimal. This paper aims to show that, contrary to conventional wisdom, the crisis in Europe is the result of an imbalance between core and noncore countries that is inherent in the euro economic model. Underpinned by a process of monetary unification and financial deregulation, core eurozone countries pursued export-led growth policies - or, more specifically, "beggar thy neighbor" policies - at the expense of mounting disequilibria and debt accumulation in the periphery. This imbalance became unsustainable, and this unsustainability was a causal factor in the global financial crisis of 200708. The paper also maintains that the eurozone could avoid cumulative imbalances by adopting John Maynard Keynes's notion of the generalized banking principle (a fundamental principle of his clearing union proposal) as a central element of its monetary integration arrangement.
\end{abstract}

Keywords: European Union; Current Account Adjustment; Financial Aspects of Economic Integration

JEL Classifications: F32, F36, O52 


\section{INTRODUCTION}

Conventional wisdom suggests that the European debt crisis - which led to severe adjustment programs sponsored by the European Union (EU) and the International Monetary Fund (IMF) in Greece, Ireland, and Portugal — was caused by fiscal profligacy on the part of peripheral or noncore countries and a welfare state model, and that the role of the common currency (the euro) along with the Maastricht Treaty (1992) was, at best, minimal. ${ }^{1}$ In particular, the German view, as Charles Wyplosz (2010) aptly named it, is that a solution for the crisis involves the eurozone's Stability and Growth Pact (SGP). The alternative view, still according to Wyplosz, is that a reform of EU institutions is needed in order to impose fiscal discipline on the sovereign national institutions, since a revised SGP would be doomed to fail.

Both views, which dominate discussions within the EU, presume that the problem is fiscal in nature. In both cases, the crisis is seen as in traditional neoclassical models - in which excessive fiscal spending implies that, at some point, economic agents lose confidence in the ability of the State to pay and service its debts, and force adjustment. Excessive spending also leads to inflationary pressures, which would be the reason, in this view, for the loss of external competitiveness and not the abandonment of exchange rate policy implicit in a common currency. In other words, the conventional view implies that the balance of payments position is the result of the fiscal crisis.

Finally, the conventional story also relegates financial deregulation to a secondary place in the explanation of the crisis. ${ }^{2}$ The idea is that if countries had balanced their budgets and avoided the temptation to create a welfare state, then excessive private spending would not have

\footnotetext{
${ }^{1}$ The euro was initially introduced as an accounting currency on January 1, 1999, replacing the former European Currency Unit (ECU) at a ratio of one-to-one. The euro entered circulation on January 1, 2002. Seventeen out of 27 member states of the European Union use the euro as a common currency. These are: Belgium, Ireland, France, Luxembourg, Austria, Slovakia, Germany, Greece, Italy, Malta, Portugal, Finland, Estonia, Spain, Cyprus, the Netherlands, and Slovenia. Among these, Austria, Belgium, France, Germany, and the Netherlands are referred to as core countries. Greece, Ireland, Italy, Portugal, and Spain are referred to as nonccore or peripheral countries. The member countries of the European Union which have not adopted the euro are Bulgaria, the Czech Republic, Denmark, Latvia, Lithuania, Hungary, Poland, Romania, Sweden, and the United Kingdom.

${ }^{2}$ See Soros 2010 for a different view. Soros understands the European Crisis as a banking rather than a fiscal crisis. More recently Soros (2011) has argued that the European Crisis is a by-product of the 2008 Crash which forced the financial system to "substitute the sovereign credit of governments for the commercial credit that had collapsed" (Soros 2011). From here, it follows that the crisis made the health of the European Banks fall prey to the state of European public finances. Note also that, in spite of the blame placed on lax government finances, there is broad recognition that European governments have injected significant bailout packages into the financial sector, and that this was necessary. As of September 2011, available data for Ireland, Greece, and Spain show that governments' support to the financial sector net of its estimated recovery amounted to 38 percent, 5.4 percent, and 2.1 percent of their respective GDP. See IMF 2011a.
} 
resulted from perverse public policy incentives, and investors and banks would have been more aware of the risks involved. So, what is needed in Europe is a good dose of tough love. Noncore countries must adopt a realistic position regarding their fiscal accounts and ensure the compliance with the budget thresholds agreed upon in the Maastricht Treaty, as well as renounce their welfare state objectives. A generalized commitment to fiscal discipline will allow Europe's economy to bounce back to its trend - often associated with some measure of the natural rate of unemployment - of its own volition, without the need for fiscal stimulus.

The old Treasury View, which Keynes and his disciples fought for back in the 1930s, is alive and well not just in academia, but also in the corridors of power, Finance Ministries, Central Banks, and international financial organizations which have been instrumental in the response to the crisis. ${ }^{3}$ This paper presents an alternative view of the European crisis.

It sustains that, contrary to conventional wisdom, the euro, and its effects on external competitiveness - and particularly on the management of macroeconomic policy (both fiscal and monetary) — and financial deregulation are central to explaining the crisis.

More precisely, arguing from an aggregate demand perspective, this paper shows that the crisis in Europe is the result of an imbalance between core and noncore countries inherent to the euro economic model. ${ }^{4}$ Underpinned by a process of monetary unification and financial deregulation, core countries in the eurozone pursued export-led growth policies or, more specifically, "beggar thy neighbor" policies at the expense of mounting disequilibria and debt accumulation in the noncore countries or periphery. This imbalance became unsustainable and surfaced in the course of the Global Crisis (2007-2008). Unfortunately, due to the fact that, in a crisis, governments must increase expenditure (even if only through automatic stabilizers) in order to mitigate its impact, while at the same time revenues tend to decline (due to output contraction or outright recession), budget deficits are inevitable and emerge as a favorite cause of the crisis itself.

The remainder of the paper is divided into five sections. The proceeding section provides a simple post-Keynesian heuristic model, providing an integral explanation of the crisis and a foundation for arguing that the fiscal crisis - which demands a renegotiation of currents debts-

\footnotetext{
${ }^{3}$ For a survey of fiscal policy responses to the crisis, see Pérez-Caldentey and Vernengo 2010.

${ }^{4}$ This is essentially the same point made by Papadimitriou and Wray (2011); in other words, that this problem is not due to profligate spending by some nations but rather the setup of the European Monetary Union (EMU) itself. Also, it should be pointed out that several post-Keynesians, e.g. Philip Arestis, Victoria Chick, and Wynne Godley, to mention a few, had been critical of the EMU over the years.
} 
is not at the heart of the crisis. It was, in fact, a result of the overall crisis. The following section describes the process of financial liberalization, deregulation, and integration in Europe, and its effects on financial flows and on the banking system of core and noncore countries. The third section explains, using some key macroeconomic features, the contradictions inherent to the euro economic model. The last section provides some conclusions and sorts out the facts and the myths about the European crisis. A central conclusion is that the solution to the European crisis requires a profound reform of the euro institutionality and its core principles, and not simply a fiscal or financial reform. A monetary arrangement such as the euro must include Keynes' generalized banking principle, which ensures the recycling of surpluses and that the burden of adjustment be shared by both debtor and creditor economies.

\section{MODELING WHAT TYPE OF CRISIS?}

It is essential to distinguish first between an external and an internal debt crisis. Further, it is also important to note that an external crisis could be a balance of payments or currency crisis in which debt restructuring is unnecessary; or a debt crisis in which default is unavoidable.

However, it must be noted that both kinds of crises are intertwined in the conventional literature. $^{5}$

In fact, in the traditional currency crisis models (e.g. Krugman 1979), the original source of the external crisis is a domestic debt crisis. Even more recent models - which include the role of self-fulfilling expectations and the role of financial sector imbalances (e.g. Krugman 1999)remain committed to the assumption that public sector finances are central to currency crises. ${ }^{6}$

As in the case of the EU after the adoption of the euro in 1999, an important characteristic of public debt is that it is denominated in a currency that the sovereign national units do not directly control, and it is akin to foreign denominated debt. Further, since the euro members cannot devalue their currencies with respect to each other, the traditional result of currency crisis models (that is, a severe devaluation of the national currency) cannot occur-at least not for the national units.

\footnotetext{
${ }^{5}$ In particular, the literature on domestic debt default is somewhat unclear on the reasons for governments to reduce the value of debt by monetizing debt-which is, in monetarist fashion, presumed to cause inflation no matter what - or to outright default on its obligations. See, for example, Calvo 1988. In fact, public debt denominated in domestic currency can always be monetized, so there is no reason for default - and in many circumstances, when the economy is not close to full employment in particular, it might not be inflationary to do so.

${ }^{6}$ For a discussion of currency crisis models, see Burnside et al. 2007.
} 
The adjustment mechanism, in such a case, must be on the level of activity. ${ }^{7}$ Thus, the model we develop assumes a fixed nominal exchange rate, as well as assuming that changes in the level of output are central for balance of payments adjustment.

The rate of change of the real exchange rate behaves according to the following rule:

$$
\frac{\dot{\varepsilon}}{\varepsilon}=(\alpha-1) \frac{\dot{p}}{p}+\phi \frac{f f}{f f} ; 0<\mathrm{a}<1, \phi>0
$$

where e stands for real exchange rate, $\mathrm{p}$ for domestic price level, and ff are financial flows. ${ }^{8}$ For this and the other equations of the model, dots refer to changes in levels of the variables and asterisks for foreign variables. Thus, equation (1) states that the real exchange rate is an inverse function of the rate of inflation, and is positively related to financial flows.

In turn, financial flows (ff) are postulated as dependent upon the degree of financial liberalization (FL) and on capacity utilization, to which they respond positively. In other words, real variables, and not just financial, might also affect the flows off capital. That is,

$$
\frac{f f}{f f}=\gamma\left(i-i^{*}\right)+\beta(\kappa-y)+\psi F L ; \mathrm{g}<0, \beta>0,0<\psi<1
$$

where $\mathrm{k}$ is the capital stock, $\mathrm{y}$ is the level of output.

The next step is the description of the domestic price level dynamics. Prices are determined as a markup over costs, which is represented as: ${ }^{9}$

$$
p=\frac{w b+p * m}{(1-\pi)}
$$

where $\mathrm{w}$ is the nominal wage, $\mathrm{b}$ is the inverse of labor productivity, $\mathrm{p}^{*}$ is the price of imported goods, $\mathrm{m}$ is the import coefficient, and $\mathrm{p}$ is the share of profits in total income. Conflict over

\footnotetext{
${ }^{7}$ Ford (1962) is the classical locus of the notion that countries in the periphery adjusted their balance of payments disequilibria by variations of the level of income. Interestingly enough, this suggests that countries tied to a common currency are, in some respects, similar to peripheral countries.

${ }^{8}$ Since the nominal exchange rate is fixed, the real exchange rate is the ratio of foreign to domestic prices.

${ }^{9}$ This is in accordance with the full cost pricing tradition, but for simplicity we assume only labor and imported input costs.
} 
income distribution is represented by the behavior of firms, which increase prices whenever the share of profits fall below a certain level. This is represented as follows:

$$
\frac{p}{p}=\bar{\pi}-\pi
$$

where p-bar is the target profit share desired by capitalists. From (2), (3), and (4), we can rewrite (1) as follows:

$$
\frac{\dot{\varepsilon}}{\varepsilon}=(\alpha-1)(\bar{\pi}-1+w b+\varepsilon m)+\gamma\left(i-i^{*}\right)+\beta(\kappa-y)+\phi \psi F L
$$

Income determination follows traditional Keynesian lines, and can be written as:

$$
\frac{\dot{y}}{y}=\delta(\kappa-y)+\eta \varepsilon x+\lambda i+\mu G+\xi d ; \delta>0, \mathrm{~m}>0, \mathrm{x}>0, \lambda<0
$$

where $\mathrm{x}$ corresponds to exports, $\mathrm{i}$ the rate of interest, $\mathrm{G}$ government expenditure, and d private debt. ${ }^{10}$ Government expenditure depends on its taxing capacity ( $\left.\tau y\right)$ and on the cost to raise funds, which is given mainly by the difference in interest rates paid on a bond of a given eurozone country $\left(r_{g b}\right)$ and those paid on a German bond $\left(r_{g g b}\right)$.

$$
G=\tau y+\varphi\left(r_{g b}-r_{g g b}\right) ; 0<\tau<1 \text { and } \varphi<0 .
$$

\footnotetext{
${ }^{10}$ Equation (5) is essentially a multiplier which includes an accelerator term, which in this model suggests that accumulation would be associated with a certain capital-output ratio. The multiplier cum accelerator was termed a supermultiplier by John Hicks, and is typical of Kaldorian models of growth. For discussions of Kaldorian models, see McCombie and Thirlwall 1994 and Bortis 1997.
} 
Figure 1 Output and exchange rate dynamics

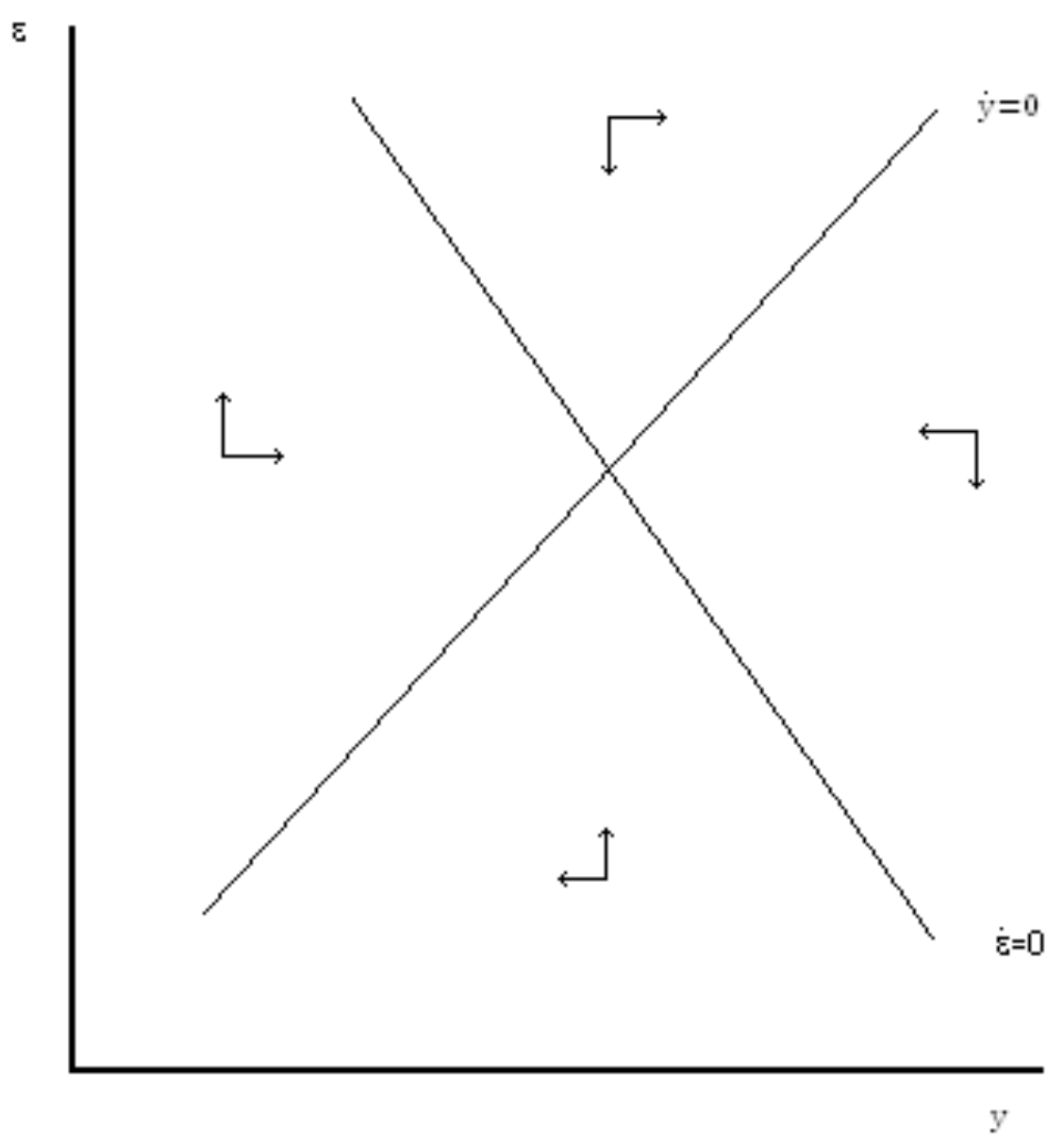

Equations (5) and (6) form a dynamic system which determines the real exchange rate and the level of income of the economy, represented in Figure 1.

Equation (2) suggests that an increase in capacity utilization tends to attract capital flows and leads to a real appreciation, which is represented by the negatively sloped e-dot schedule. Equation (6) simply suggests that exports respond positively to real exchange depreciations and lead to output increase, displayed in the positively sloped y-dot schedule. The solution of the dynamic system provides a stable node and allows for simple comparative static analysis. ${ }^{11}$

\footnotetext{
${ }^{11}$ The Jacobian matrix which determines the local stability properties of the system is: $\left[\begin{array}{cc}(\alpha-1) m & -\beta \\ \eta x & -\delta\end{array}\right]$, and if its determinant is positive and the trace is negative the system is stable as represented in Figure 1.
} 
Let's assume that wages expand. This would translate into higher domestic prices and a more appreciated real exchange rate. This would be represented by an inward shift of the e-dot schedule and would reduce the level of output (since it would have a negative impact on exports), and through the supermultiplier, would lead to a reduction in income. A financial crisis can be represented by a collapse of spending (say as a result of a fall in $\mathrm{d}$, private debt or G, public spending), which would lead to an upward shift on the y-dot schedule.

The fall in capacity utilization would lead to an outflow of capital and a depreciation of the currency - typical of currency crisis. The final effect of the combination of higher wages and a financial crisis on the real exchange rate would depend on the relative strength of both forces, but it would be unequivocally contractionary. Figure 8 shows a situation in which appreciation of the real exchange rate prevails, moving from E0 to E1. This represents the effects of the crisis in the deficit countries, where, in the absence of nominal exchange rate depreciation, the adjustment of the balance of payments must be carried by variations in the level of activity. 
Figure 2 Contraction and appreciation

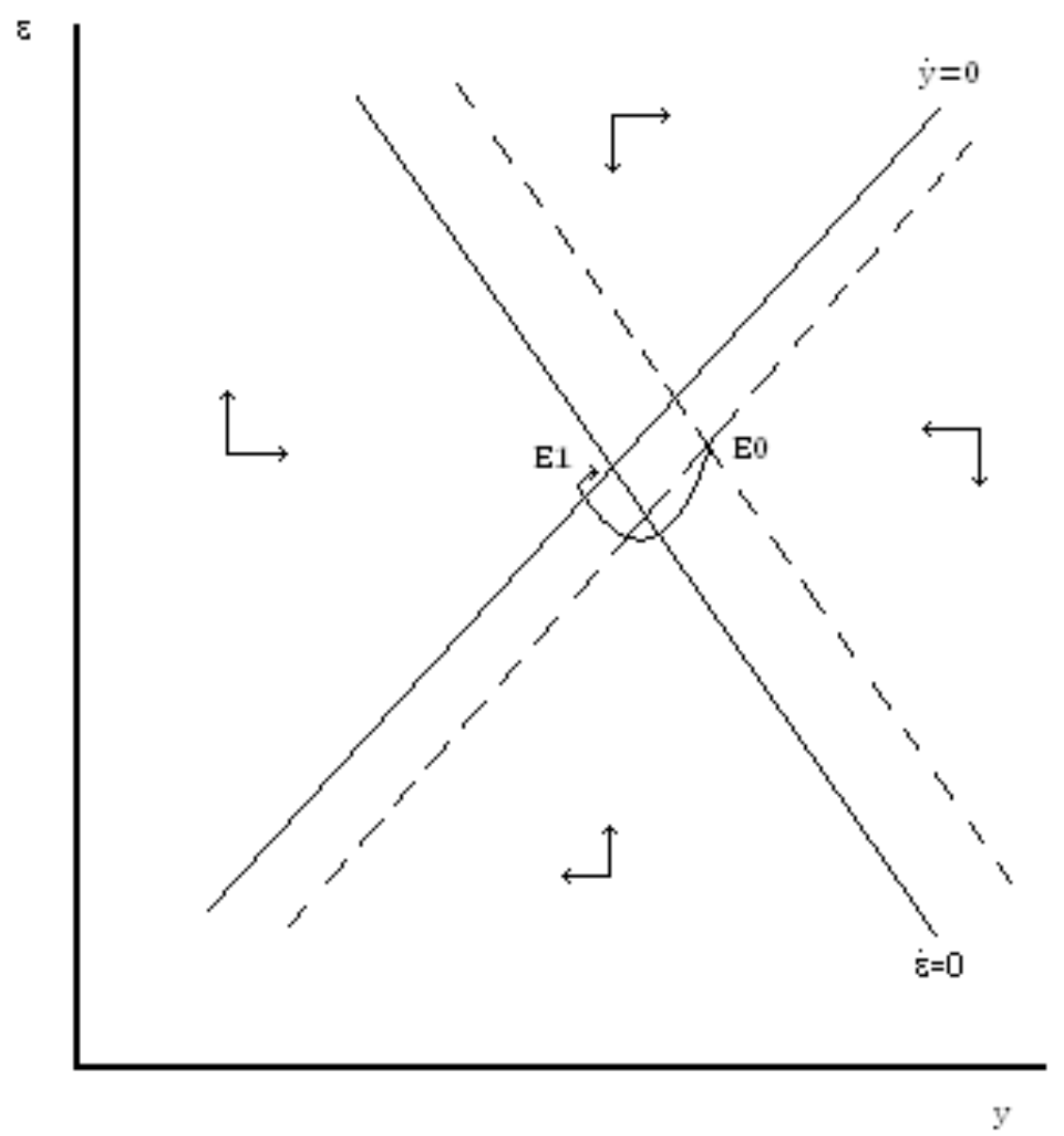

Although not explicitly modeled, it is presumed that contraction has a negative impact on tax revenue and requires an expansion of spending associated with the safety net to protect the unemployed. As a result, in the post-Keynesian perspective, the fiscal crisis (i.e. the increase in deficits and domestic debt) is the result — rather than the cause — of the external crisis.

The stylized crisis depicted in Figure 2 illustrates the European crisis in a postKeynesian framework. Higher unit labor costs in the peripheral countries of Europe (relative to core countries) led to loss of competitiveness and increasing external problems - which, combined with the financial crisis, implied a collapse of output and a fiscal crisis. The inability 
to depreciate the nominal exchange rate, and the absence of a supra-national fiscal authority who could transfer resources, implies that contraction is the solution for the external imbalances.

\section{FINANCIAL INTEGRATION/DEREGULATION IN EUROPE AND THE EURO}

The road to financial integration in Europe began in early 1957 with the signing of the Treaty of Rome, which set out the basics for the creation of a European single market for financial services. However, in spite of several initiatives in this direction, the progress was slow. Only by the late 1980s and early 1990s, spurred by the Single European Act (1987), did most European countries embark definitely on a financial liberalization strategy.

During this time, most countries lifted capital controls, deregulated interest rates, and adopted the European Directives - which are considered to be a crucial step toward the foundation of the Single Market Program in banking and financial services. ${ }^{12}$ These were meant to harmonize rules, supervision, and regulation of financial institutions, as well as to establish the principle of home country control and the so-called European Passport (branches and the provision of services across borders throughout the EC); see Table 1 below. ${ }^{13}$

The thrust for financial deregulation was further pursued by the adoption of a five-year financial harmonization program: the Financial Services Action Plan (1999).

\footnotetext{
12 "Directives" are legislative acts requiring member states to achieve specific results without dictating the means.

13 The first banking directive introduced the Single Banking License in 1989, a significant step toward the unification of banking legislation and regulation.
} 
Table 1

Financial liberalization and integration in Europe prior to the introduction of the euro

\begin{tabular}{|c|c|c|c|c|}
\hline & $\begin{array}{c}\text { Lifting of } \\
\text { capital controls }\end{array}$ & $\begin{array}{c}\text { Interest rate } \\
\text { deregulation }\end{array}$ & $\begin{array}{c}\text { First Banking } \\
\text { Directive }\end{array}$ & $\begin{array}{c}\text { Second } \\
\text { Banking } \\
\text { Directive }\end{array}$ \\
\hline Belgium & 1991 & 1990 & 1993 & 1994 \\
\hline Denmark & 1982 & 1988 & 1980 & 1991 \\
\hline France & 1990 & 1990 & 1980 & 1992 \\
\hline Germany & 1967 & 1981 & 1978 & 1992 \\
\hline Greece & 1994 & 1993 & 1981 & 1992 \\
\hline Ireland & 1985 & 1993 & 1989 & 1992 \\
\hline Italy & 1983 & 1990 & 1985 & 1992 \\
\hline Luxemburg & 1990 & 1990 & 1981 & 1993 \\
\hline Netherlands & 1980 & 1981 & 1978 & 1992 \\
\hline Portugal & 1992 & 1992 & 1992 & 1992 \\
\hline Spain & 1992 & 1992 & 1987 & 1994 \\
\hline United & 1979 & 1979 & 1979 & 1993 \\
\hline Kingdom & & & & \\
\hline Source: Buch and Heinrich 2002
\end{tabular}

The FSAP was meant to harmonize the EU Member States' rules on a whole range of financial services, including securities, banking, insurance, mortgages, pensions, and other forms of financial transactions through the implementation of 42 measures in these different areas. More specifically, its objectives included: 1) the development of a single market for wholesale financial services; 2) the creation of open and secure retail markets; 3) the establishment of clear, efficient, prudential rules and supervision of financial services; and 4) the establishment of the conditions for an optimal single financial market.

Member countries' commitment to the FSAP was reinforced by a series of initiatives including the Lisbon Agenda (2000), the re-launching of the Lisbon Strategy (2005), and the White Paper (2005). As stated in the latter:

Financial markets are pivotal for the functioning of modern economies. The more they are integrated, the more efficient the allocation of economic resources and long run economic performance will be. Completing the single market in financial services is thus a crucial part of the Lisbon economic reform process; and essential for the EU's global competitiveness (European Commission 20052010, p. 5). 
Most of the measures of the FSAP passed the EU legislative process at the end of 2003; see Kalemi-Ozcan et al. (2010). The latest available public releases show that 25 out of 27 countries of the European Union had provided information on the entry into force of the directives of the FSAP. ${ }^{14}$

The progress of financial liberalization is reflected in the Chinn-Ito index (2011), which measures openness in capital account transactions. The higher the value of the index, the greater the degree of openness of an economy to cross-border capital transactions. As Table 2 shows, the level of financial openness increased systematically throughout the 1990s, reflecting the fact that European countries - in particular, the core and noncore countries (that is, countries that adopted the euro as their common currency) — became, on average, more "financially open." Both groups of countries reached the status of full liberalization after the adoption of the euro.

\footnotetext{
${ }^{14}$ See European Commission 2011. The countries that have not provided information are Bulgaria and Rumania. The directives for which there is no information on the date of entry into force include the directives on takeover bids (2004/25), taking up and pursuit of the business of credit institutions (2006/48), capital adequacy (2006/49), transparency (2004/109), markets and financial institutions (2004/39), and money laundering (2005/60). Some of these are part of the Lamfalussy initiatives (directives 109 and 39). The money laundering is a complement to the FSAP. Since the Global Crisis the EU adopted post directives (European Commission 2011).
} 


\begin{tabular}{|c|c|c|c|c|}
\hline Chinn-Ito Index of & Eu & $\begin{array}{l}\text { Table } 2 \\
\text { pean Union } \\
\text { beralization } \\
90-2009\end{array}$ & r selected co & groupings \\
\hline & 1990-1994 & 1995-1999 & $2000-2004$ & $2005-2009$ \\
\hline Core Countries & 83.2 & 96.1 & 97.4 & 100.0 \\
\hline Noncore Countries & 19.5 & 80.5 & 96.6 & 100.0 \\
\hline Other Euro Countries & -37.9 & -9.5 & 24.7 & 81.3 \\
\hline Non-Euro Countries & 8.8 & 39.0 & 66.9 & 87.9 \\
\hline $\begin{array}{l}\text { Note: The Chinn-Ito index is } \\
\text { sample. Thus, a value of } 100 \\
\text { Core countries include: Aust } \\
\text { include: Greece, Ireland, Italy } \\
\text { Slovak Republic, and Sloven } \\
\text { Source: Based on Chin and It }\end{array}$ & $\begin{array}{l}\text { ressed in term } \\
\text { ans complete li } \\
\text { Belgium, Fran } \\
\text { ortugal, and } \mathrm{Sp} \\
\text { Non-euro coun } \\
008 \text {. }\end{array}$ & $\begin{array}{l}f \text { its highest } \mathrm{v} \\
\text { ralization. } \\
\text { Germany, an } \\
\text { n. Other euro } \\
\text { es are compris }\end{array}$ & $\begin{array}{l}\text { or all countric } \\
\text { Netherlands. } \\
\text { ries include: } \\
\text { Sweden and }\end{array}$ & $\begin{array}{l}\text { idered in their } \\
\text { re countries } \\
\text { Malta, the } \\
\text { ited Kingdom. }\end{array}$ \\
\hline
\end{tabular}

The process of harmonization and intra-European liberalization of flows was parallel to the process of the establishment and introduction of the euro, which came into effect on January 1, 2002. The establishment of a single currency and monetary union was based on prior compliance with convergence criteria including: inflation, fiscal balances, exchange rate, and interest rate convergence set out in the Maastricht Treaty. ${ }^{15}$

Exchange rate convergence was meant to avoid the manipulation of the exchange rate prior to the establishment of a monetary union in order to achieve an improved competitive position at the time of entry. The justification of inflation and budget convergence was the avoidance of an inflationary bias in the monetary union.

Fiscal convergence meant, in practice, that governments had to achieve a ratio of planned or actual government deficit to GDP at market prices equal to or less than 3 percent at any time. The 3 percent budget sustainability criterion, which was independent of the cycle, combined with earlier legislation contained in the Pact for Growth and Stability (1997), required

\footnotetext{
${ }^{15}$ The four convergence criteria are defined in article 109j of the Maastricht Treaty (in its Chapter IV under the heading Transitional Provisions), and are explained in one of the protocols. The interest rate convergence criterion is defined as "the durability of convergence achieved by the Member State and of its participation in the Exchange Rate Mechanism of the European Monetary System being reflected in the long-term interest rate levels." (European Council 1992a, p. 24) This is explained in the protocols as follows: "The criterion on the convergence of interest rates... of this Treaty shall mean that, observed over a period of one year before the examination, a Member State has had an average nominal long-term interest rate that does not exceed by more than 2 percentage points that of, at most, the three best performing Member States in terms of price stability. Interest rates shall be measured on the basis of long term government bonds or comparable securities, taking into account differences in national definitions" (European Council 1992b, p. 30).
} 
European countries to balance their budget or be in a surplus position in the medium run; i.e., countries had to run surpluses in good times in order to offset deficits in bad times.

Interest rate convergence is interpreted as a measure to limit arbitrage opportunities, thus limiting capital gains and losses prior to the entry into force of the monetary union. However, this criterion is considered redundant (Kenen 1995; De Grauwe 2003). In fact, financial deregulation, capital mobility, and exchange rate convergence (and eventually the adoption of a unique currency) lead to nominal interest rate convergence. In this sense, as put by De Grauwe: "Once countries were expected to join European Monetary Union (EMU), long-term interest rates converged automatically" (Ibid., p. 136). In addition, under interest rate parity theorem conditions, nominal exchange rate and inflation convergence were tantamount to real, uncovered interest parity conditions.

The process of harmonization of EU financial legislation and regulation, and the process of adoption of a single currency led to an increase in cross-border financial flows and, as expected, a process of convergence of interest rates. The growth of financial flows can also be ascertained by the expansion of the balance sheet of European countries. As shown in Table 3, the external position of member countries of the European Union banks (core, noncore, and non-euro countries included) vis-à-vis all sectors in assets and liabilities as percentages of GDP increased rapidly throughout the liberalization and the adoption of euro period.

A similar phenomenon occurred with the evolution of the size of capital markets; see Table 4. The size of capital measured in terms of GDP increased by more than a third in core countries, and more than doubled in noncore countries during the consolidation period of financial liberalization and regulation, and following the adoption of the euro. ${ }^{16}$

\footnotetext{
${ }^{16}$ Available evidence indicates that the majority of assets are nationally owned- 75 percent, according to Allen et al. 2011.
} 


\begin{tabular}{|c|c|c|c|}
\hline \multicolumn{4}{|c|}{$\begin{array}{c}\text { Table } 3 \\
\begin{array}{c}\text { Growth in balance sheets in the European Union measured by the external position of } \\
\text { banks (assets and liabilities) vis-à-vis all sectors as percentages of GDP } \\
\text { 1990-2011 (Averages) }\end{array}\end{array}$} \\
\hline \multicolumn{4}{|c|}{ Assets } \\
\hline Period & Core countries & Noncore countries & Non-Euro \\
\hline $1990-1995$ & 47.40 & 22.52 & 58.97 \\
\hline 1996-2001 & 61.96 & 55.74 & 76.40 \\
\hline $2002-2010$ & 118.31 & 96.15 & 131.37 \\
\hline \multicolumn{4}{|c|}{ Liabilities } \\
\hline Period & Core countries & Noncore countries & Non-Euro \\
\hline 1990-1995 & 41.79 & 19.89 & 63.26 \\
\hline 1996-2001 & 63.40 & 60.31 & 84.35 \\
\hline $2002-2010$ & 102.44 & 107.22 & 148.44 \\
\hline \multicolumn{4}{|c|}{$\begin{array}{l}\text { Note: Core countries include: Austria, Belgium, France, Germany, and the Netherlands. Noncore countrie } \\
\text { include: Greece, Ireland, Italy, Portugal, and Spain. Non-euro countries include Sweden and the United } \\
\text { Kingdom. } \\
\text { Source: Bank for International Settlements 2011, Table 2A. }\end{array}$} \\
\hline
\end{tabular}

\begin{tabular}{|c|c|c|c|}
\hline \multicolumn{4}{|c|}{$\begin{array}{c}\text { Table } 4 \\
\text { Size of Capital Markets 1990-2009 as percentage of GDP in core, noncore, and } \\
\text { eurozone countries of Europe } \\
1990-2009 \text { (Averages) }\end{array}$} \\
\hline & Core & Noncore & Eurozone \\
\hline 1990-1994 & 1.61 & 0.79 & $\mathrm{n} / \mathrm{a}$ \\
\hline 1995-1999 & 2.04 & 1.14 & 1.76 \\
\hline $2000-2004$ & 2.51 & 1.96 & 2.27 \\
\hline 2005-2009 & 2.82 & 3.22 & 2.63 \\
\hline
\end{tabular}

The empirical evidence that has attempted to isolate both the effects of financial liberalization and deregulation and those of the euro on the increase in cross-border flows highlights the importance of both sets of policy, but attributes greater importance to the latter (i.e., the adoption of the euro). This is explained mainly by to the elimination of exchange rate risk due to the adoption of a single currency (Ibid.). Recent evidence presented by Kalemi- 
Ozcan et al. (2010) indicates that bilateral bank holdings and transactions among the euro area economies increased by roughly 40 percent following the adoption of the euro. ${ }^{17}$

At the same time, financial liberalization and the process of adoption of the euro brought about a clear and marked convergence in both short and long term interest rates. Figure 3 below shows that the secondary market yields of 10 -year government bonds for core and noncore (or peripheral) countries stood at 6 percent and 10 percent, respectively, and reached 5 percent for both country groupings in January 2002 (the month and year the euro was implemented). As well, the dispersion for all eurozone member states declined from 5 percent to 1 percent in the same period, and registered further declines thereafter until the 2008-2009 Global Crisis.

Figure 3 European Union. Average secondary market yields of government bonds with maturities of close to ten years for core and noncore (peripheral) countries and dispersion, in percentages. April 1993-April 2011 (Monthly Data).

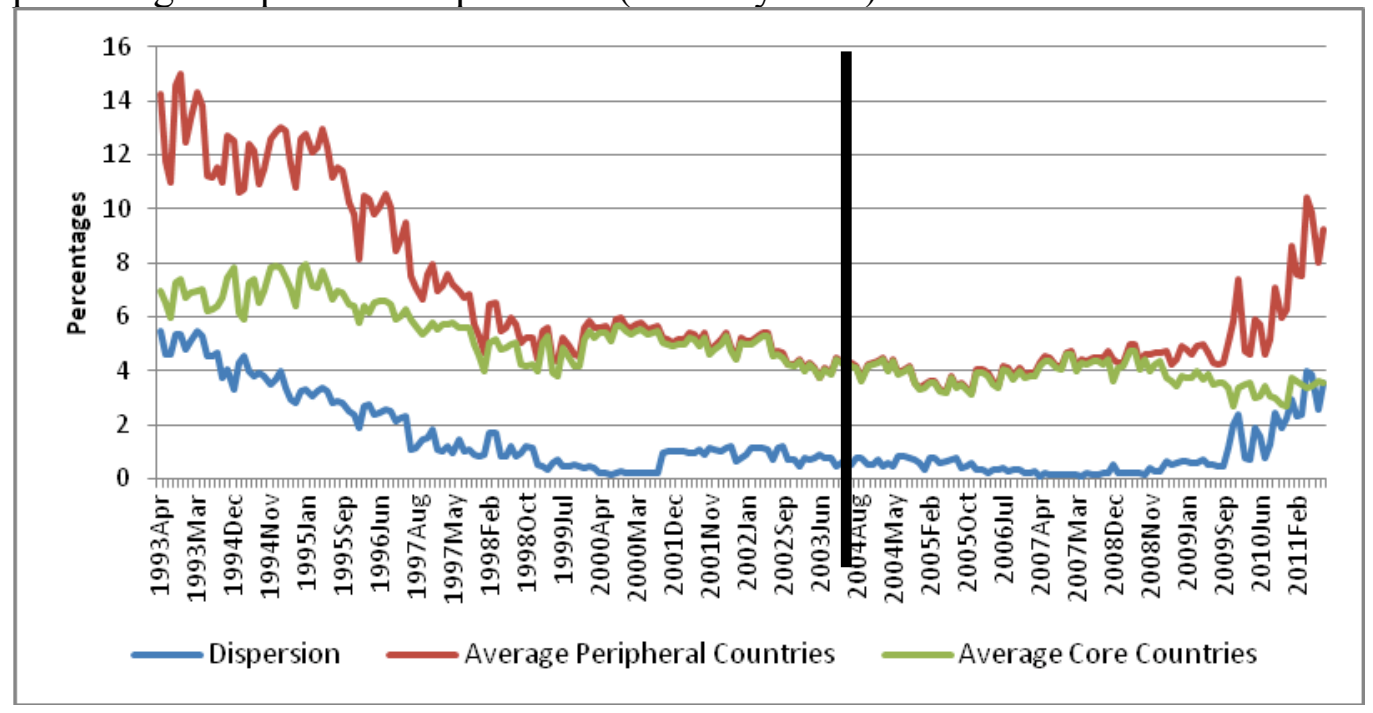

Source: Authors' own, based on European Central Bank 2011.

Interest rate convergence lowered interest rate margins especially in noncore countries. Between 1990-1995 and 1996-2001, interest rate margins - as a percentage of total earning assets - declined from 3.9 percent to 2.8 percent, while these remained roughly constant in core countries. This translated into a decline in the rate of return over assets in noncore countries from 0.8 percent to 0.5 percent between 1990-1995 and 1996-2001; see Table 5 below.

\footnotetext{
${ }^{17}$ Other estimates reach a much higher figure.
} 
In the face of a decline in ROA (as in the case of noncore countries between 1990-1995 and 1996-2007), or for a roughly constant ROE (as in the case of both core and noncore countries between 1996-2001 and 2002-2007), the levels of profitability (ROE) of the financial system can be maintained or increased by higher levels of leverage (or indebtedness). ${ }^{18}$ The levels of leverage were particularly high in some of the core countries. Available evidence on Germany, provided by Bloomberg, shows that leverage for the major banks increased on average from 27 to 45 between 1996 and 2007. As well, data for 2007 for 14 of the major financial institutions of Europe (located in core countries) indicates that the average leverage ratio was 34 (with a maximum of 50). ${ }^{19}$

${ }^{18}$ The simple banking profit identity, also known as the Du Pont de Nemours and Company return over equity (ROE) decomposition, states that the ratio of earnings to equity equals the product of the ratio of earnings to assets and assets to equity. That is,

$$
\begin{aligned}
& \frac{\text { Earnings }}{\text { Equity }}=\left(\frac{\text { Earnings }}{\text { Assets }}\right) *\left(\frac{\text { Assets }}{\text { Equity }}\right) \\
& \text { where } \frac{\text { Assets }}{\text { Equity }}=\text { Leverage and thus, } \\
& \frac{\text { Earnings }}{\text { Equity }}=\frac{\text { Earnings }}{\text { Asets }} * \text { Leverage }
\end{aligned}
$$

As a result, for a given assets to equity ratio, the greater the leverage, the greater the profit opportunities captured by the ratio of earnings over equity.

${ }^{19}$ To put things in perspective: If the leverage ratio is equal to 10 , then debt and equity finance represent 90 percent and 10 percent of the financial intermediary's acquisition of assets, respectively. With a leverage ratio of 34, the respective debt and equity ratios are 97 percent and 3 percent, respectively. 


\begin{tabular}{|c|c|c|c|c|c|c|}
\hline \multicolumn{7}{|c|}{$\begin{array}{c}\text { Table } 5 \\
\text { ed indicators of the performance of the banking system }\end{array}$} \\
\hline \multicolumn{7}{|c|}{ Core Countries } \\
\hline Period & Financial Deepening & Costs/Income & Interest margins & ROA & Concentration & Z-Score \\
\hline 1990-1995 & 92.5 & 72.8 & 2.3 & 0.3 & 67.2 & 15.4 \\
\hline $1996-2001$ & 103.5 & 67.8 & 2.5 & 0.9 & 67.2 & 9.4 \\
\hline $2002-2007$ & 108.2 & 70.2 & 2.1 & 1.0 & 68.2 & 7.3 \\
\hline \multicolumn{7}{|c|}{ Noncore countries } \\
\hline Period & Financial Deepening & Costs/Income & Interest margins & ROA & Concentration & Z-Score \\
\hline 1990-1995 & 56.8 & 67.6 & 3.9 & 0.8 & 72.1 & 23.9 \\
\hline 1996-2001 & 73.3 & 70.8 & 2.8 & 0.5 & 66.7 & 25.6 \\
\hline $2002-2007$ & 112.8 & 66.5 & 2.2 & 0.4 & 68.9 & 15.8 \\
\hline \multicolumn{7}{|c|}{ Eurozone Countries } \\
\hline Period & Financial Deepening & Costs/Income & Interest margins & ROA & Concentration & Z-Score \\
\hline 1990-1995 & 77.0 & 65.8 & 3.1 & 0.6 & 73.7 & 18.1 \\
\hline 1996-2001 & 77.3 & 69.9 & 2.7 & 0.7 & 68.8 & 12.7 \\
\hline $2002-2007$ & 101.3 & 67.6 & 2.4 & 0.8 & 70.8 & 10.4 \\
\hline $\begin{array}{l}\text { Note: Core countri } \\
\text { "Financial deepeni } \\
\text { of total income of a } \\
\text { earning) assets. RO } \\
\text { Score" is estimated } \\
\text { Source: Based on E }\end{array}$ & $\begin{array}{l}\text { de: Austria, Belgium, Fra } \\
\text { neasured by private credit } \\
\text { mercial banks. "Interest m } \\
\text { ls "rate of return over ass } \\
\text { A+equity/assets/sd(ROA) } \\
\text { d Demirgüç-Kunt 2009. }\end{array}$ & $\begin{array}{l}\text { Germany, and the } \\
\text { osit money banks } \\
\text { ns" equals the acc } \\
\text { "Concentration" } \\
\text { standard deviatio }\end{array}$ & $\begin{array}{l}\text { herlands. Noncore } \\
\text { other financial inst } \\
\text { ing value of a bank' } \\
\text { s to assets of three } 1 \\
\text { ROA, sd(ROA), is }\end{array}$ & $\begin{array}{l}\text { iclude: } \\
\text { Costs/I } \\
\text { st reve } \\
\text { ks as a } \\
\text { is a } 5 \text {-y }\end{array}$ & $\begin{array}{l}\text { eland, Italy, Portu } \\
\text { measured as total } \\
\text { hare of its interest } \\
\text { sets of all comme } \\
\text { g average. }\end{array}$ & $\begin{array}{l}\text { nd Spain. } \\
\text { as a share } \\
\text { ng (total } \\
\text { anks. " } Z \text { - }\end{array}$ \\
\hline
\end{tabular}


The freedom of financial flows which moved throughout Europe and abroad, low borrowing costs, easy access to liquidity via leveraging, and no exchange rate risk provided a false sense of prosperity in a low-risk environment.

\section{STYLIZED FACTS OF THE EURO IMBALANCES}

The constraints imposed on government activities in the name of 'fiscal sustainability' by the Maastricht Treaty (jointly with the Stability and Growth Pact) placed private expenditure and exports at the center stage of aggregate demand, and as the linchpins of growth.

Core countries were able to pursue wage moderation and restraint policies to contain labor costs below those of noncore countries - as in the case of Germany and Austria, and more generally, in the case of the other countries (Belgium, France, and the Netherlands). As Table 6 below shows, between 2000 and 2007, unit labor costs remained essentially constant, increasing merely 7 percent on average for core countries. Contrarily, labor unit costs for noncore countries witnessed a clear upward trend, increasing by 24 percent for the same period. Under a fixed regime, and within a context where the bulk of trade is intraregional (roughly around 70 percent using the export market share), this amounted to a real devaluation, and a basis to pursue exportled growth policies — and indeed, more precisely, "beggar thy neighbor" policies. ${ }^{20}$

Noncore countries did not have the means to counteract and offset core countries' "beggar thy neighbor" policies. The euro common currency arrangement precludes nominal depreciations to compensate for the increase in wages in the periphery relative to those in core countries. Further, there are few mechanisms for large fiscal transfers which would compensate the loss of output associated with reduced competitiveness in the countries with higher costs.

\footnotetext{
${ }^{20}$ Computations were undertaken with WITS (2011) for the 27 European Union member states for 2006 using the SITC Rev.3.
} 


\begin{tabular}{|c|c|c|c|}
\hline \multicolumn{4}{|c|}{$\begin{array}{c}\text { Table } 6 \\
\text { Average unit labor costs indices for noncore and core }\end{array}$} \\
\hline & $\begin{array}{l}\text { Average noncore } \\
\text { countries }\end{array}$ & $\begin{array}{l}\text { Average core } \\
\text { countries }\end{array}$ & $\begin{array}{l}\text { Ratio of noncore to core } \\
\text { country unit labor costs }\end{array}$ \\
\hline 2000 & 100 & 100 & 1.00 \\
\hline 2001 & 102.5 & 102.4 & 1.00 \\
\hline 2002 & 106.5 & 104.6 & 1.02 \\
\hline 2003 & 110.1 & 106.0 & 1.04 \\
\hline 2004 & 112.4 & 106.0 & 1.06 \\
\hline 2005 & 116.9 & 106.7 & 1.10 \\
\hline 2006 & 120.4 & 107.4 & 1.12 \\
\hline 2007 & 124.3 & 108.5 & 1.15 \\
\hline 2008 & 130.1 & 111.5 & 1.17 \\
\hline 2009 & 132.0 & 116.7 & 1.13 \\
\hline 2010 & 129.5 & 116.2 & 1.11 \\
\hline
\end{tabular}

Faced with higher relative labor costs and real exchange appreciations, which undermined their external competitiveness, noncore countries were left with the option of growing by increasing internal aggregate demand. This is illustrated in Figure 4, which shows gross formation of fixed capital (GFFC; i.e. investment demand) as a percentage of GDP between 1996 and 2007, the year prior to the explosion of the Global Crisis. In 1996, both core and noncore countries had a similar GFFC relative to GDP (20 percent and 21 percent respectively). Thereafter, the GFFC shot up in noncore countries, while in core countries it stagnated or declined. From the year of the implementation of the euro (2002) until 2007, GFFC in noncore countries was roughly 4 percentage points of GDP above that of core countries. ${ }^{21}$

\footnotetext{
${ }^{21}$ A similar exercise using domestic final consumption over GDP, instead of investment, shows a similar result. For the period 2002-2007, final consumption averaged 78 percent and 75 percent of GDP for noncore and core countries, respectively.
} 
Figure 4 Eurozone: Gross formation of fixed capital (GFFC) as a percentage of GDP for core and noncore countries (1996-2007)

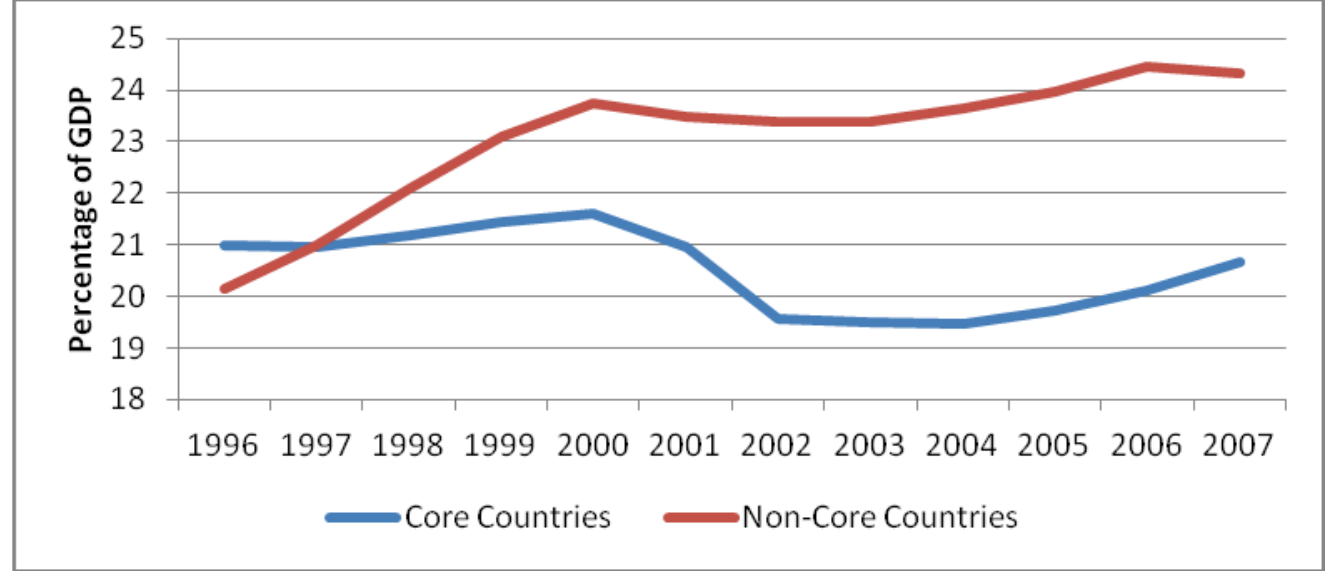

Source: Based on World Bank 2011

Greater domestic demand and higher labor costs (real exchange rate appreciation) in the periphery had a negative impact on its constituent countries' external positions. As shown in Figure 5 and Table 7 below, the current account balance for noncore countries deteriorated during the finalization of the European integration process, and even more so following the introduction of the euro. In other words, it seems fairly reasonable to believe that unit labor costs impacted the external performance of European economies, and that the common currency was central to the outcome.

Contrarily, core countries' external positions remained in surplus and improved following the introduction of the euro. In 2001, core countries registered, on average, a surplus on their current account equivalent to 0.9 percent of GDP. In 2007, the surplus had increased to 3.6 percent of GDP, on average (see Appendix for data at the country level). ${ }^{22}$

\footnotetext{
${ }^{22}$ In the period 2001-2007, at the country level, only France in 2005, 2006, and 2007, and Austria in 2001 registered deficits in the current accounts. With the exception of France in 2007, the current account deficits were below 1 percent of GDP. See Appendix.
} 
Figure 5 Current account balances for noncore countries 1980-2010, as percentages of GDP

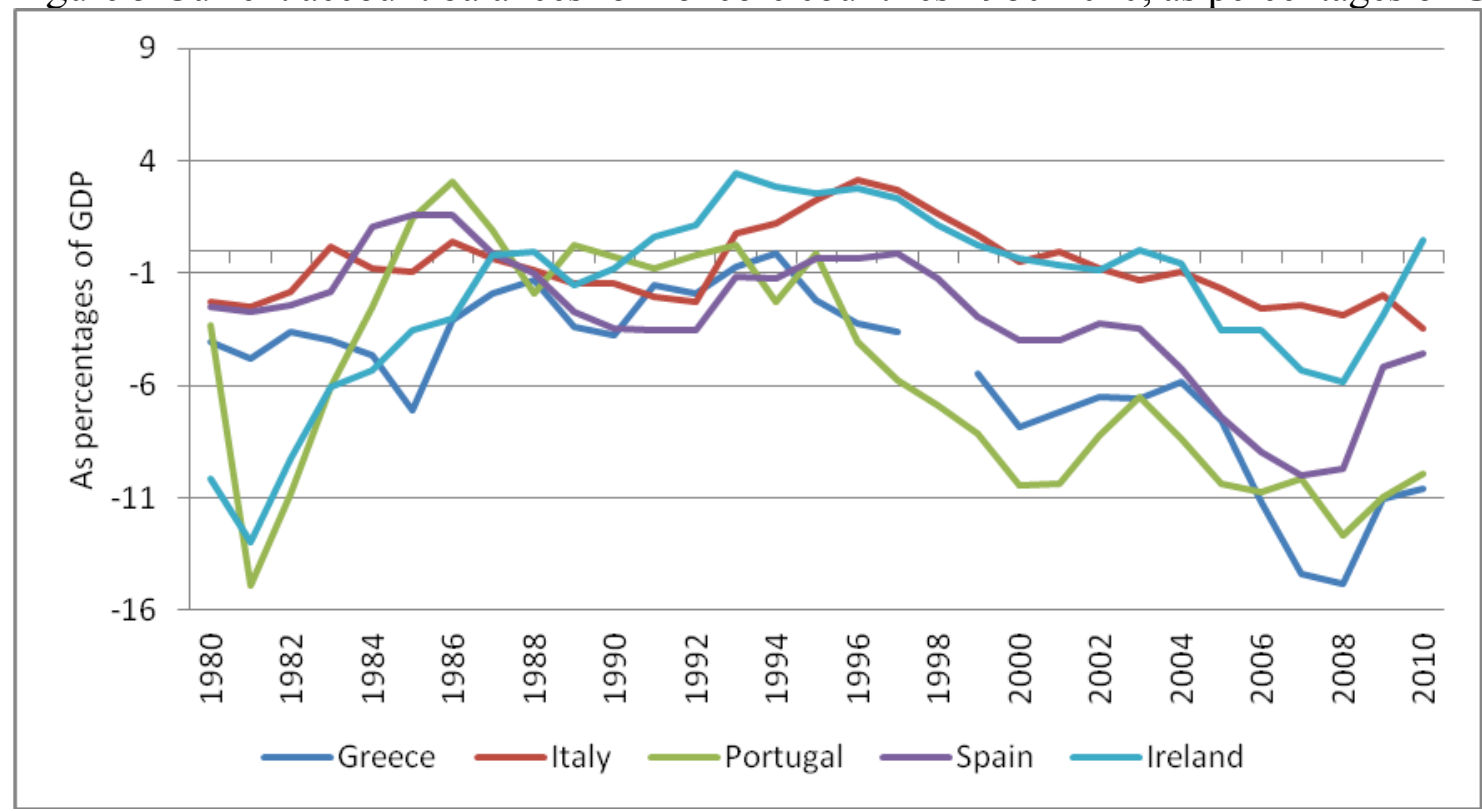

Source: World Bank 2011

Table 7

Financial balances of core and noncore countries as percentages of GDP, 2001-2010 (averages)

\begin{tabular}{|c|c|c|c|c|c|c|c|c|c|c|}
\hline & 2001 & 2002 & 2003 & 2004 & 2005 & 2006 & 2007 & 2008 & 2009 & 2010 \\
\hline \multicolumn{10}{|c|}{ Current Account Balance } \\
\hline $\begin{array}{c}\text { Average Core } \\
\text { Countries }\end{array}$ & 0.9 & 2.6 & 2.7 & 3.6 & 3.2 & 3.9 & 3.6 & 2.5 & 2.5 & 3.0 \\
\hline $\begin{array}{c}\text { Average } \\
\text { Noncore } \\
\text { Countries }\end{array}$ & -4.4 & -3.9 & -3.6 & -4.2 & -6.1 & -7.4 & -8.5 & -9.2 & -6.4 & -5.6 \\
\hline \multicolumn{10}{|c|}{ Fiscal Balance } \\
\hline $\begin{array}{c}\text { Average Core } \\
\text { Countries }\end{array}$ & -1.0 & -2.3 & -2.8 & -2.4 & -2.3 & -0.8 & -0.6 & -1.0 & -5.5 & -5.0 \\
\hline $\begin{array}{c}\text { Average } \\
\text { Noncore } \\
\text { Countries }\end{array}$ & -2.3 & -2.3 & -2.4 & -2.7 & -2.6 & -1.7 & -1.8 & -5.5 & -11.3 & 13.2 \\
\hline \multicolumn{10}{|c|}{ Private Sector Balance } \\
\hline $\begin{array}{c}\text { Average Core } \\
\text { Countries }\end{array}$ & 1.5 & 4.4 & 4.9 & 5.5 & 5.0 & 4.5 & 4.1 & 3.2 & 6.8 & 6.9 \\
\hline $\begin{array}{c}\text { Average } \\
\text { Noncore } \\
\text { Countries }\end{array}$ & -2.1 & -1.6 & -1.2 & -1.5 & -3.5 & -5.7 & -6.7 & -3.7 & 4.9 & 7.5 \\
\hline
\end{tabular}


Yet, while the external sector deteriorated, and contrary to conventional wisdom, noncore countries managed to maintain fiscal positions within the guidelines set out in the Maastricht Treaty. Following the adoption of the euro and until the onset of the crisis, all noncore countries' fiscal deficits, on average, were below 3 percent of GDP and, with the exception of 2006 and 2007, were below or at the level of average core countries' fiscal deficits.

Moreover, a more detailed analysis at the country level also shows that fiscal deficits were not endemic to noncore countries. Ireland and Spain, two noncore countries, were able to reach fiscal surpluses. Ireland's fiscal accounts were continually in surplus between 2001 and 2007. Spain was able to register budget surpluses between 2005 and 2007; see Appendix.

The expansion of internal demand was sustained by the decline in interest rates (i.e., interest rate convergence) in the noncore countries and, more importantly, by the process of financial integration and deregulation. The latter permitted finance to flow from core to noncore countries where the relative rates of return were higher. Easy access to finance permitted the funding of increasing current account deficits and also private debt accumulation.

As shown in Table 7 above, private balances show a rising average deficit for noncore countries since the introduction of the euro. In 2002, the private sector deficit of the noncore countries averaged 1.6 percent of GDP and increased to reach 6.7 percent of GDP in 2007.

The private sector deficits are, to a great extent, the result of household indebtednessparticularly significant in some of the peripheral countries of Europe like Ireland, Portugal, and Spain, and to a lesser degree in Greece and Italy. As noted by Zarco (2009), the total liabilities of households and non-profit institutions serving households as a percentage of their disposable income increased in most countries between 2000 and 2007. It was over 100 percent in 2007 for Germany, Spain, and Portugal, and was over 200 percent for Denmark in the same year (Zarco 2009, p.4). 
Figure 6 Growth rate of mortgage loans for selected European countries (1999-2007)

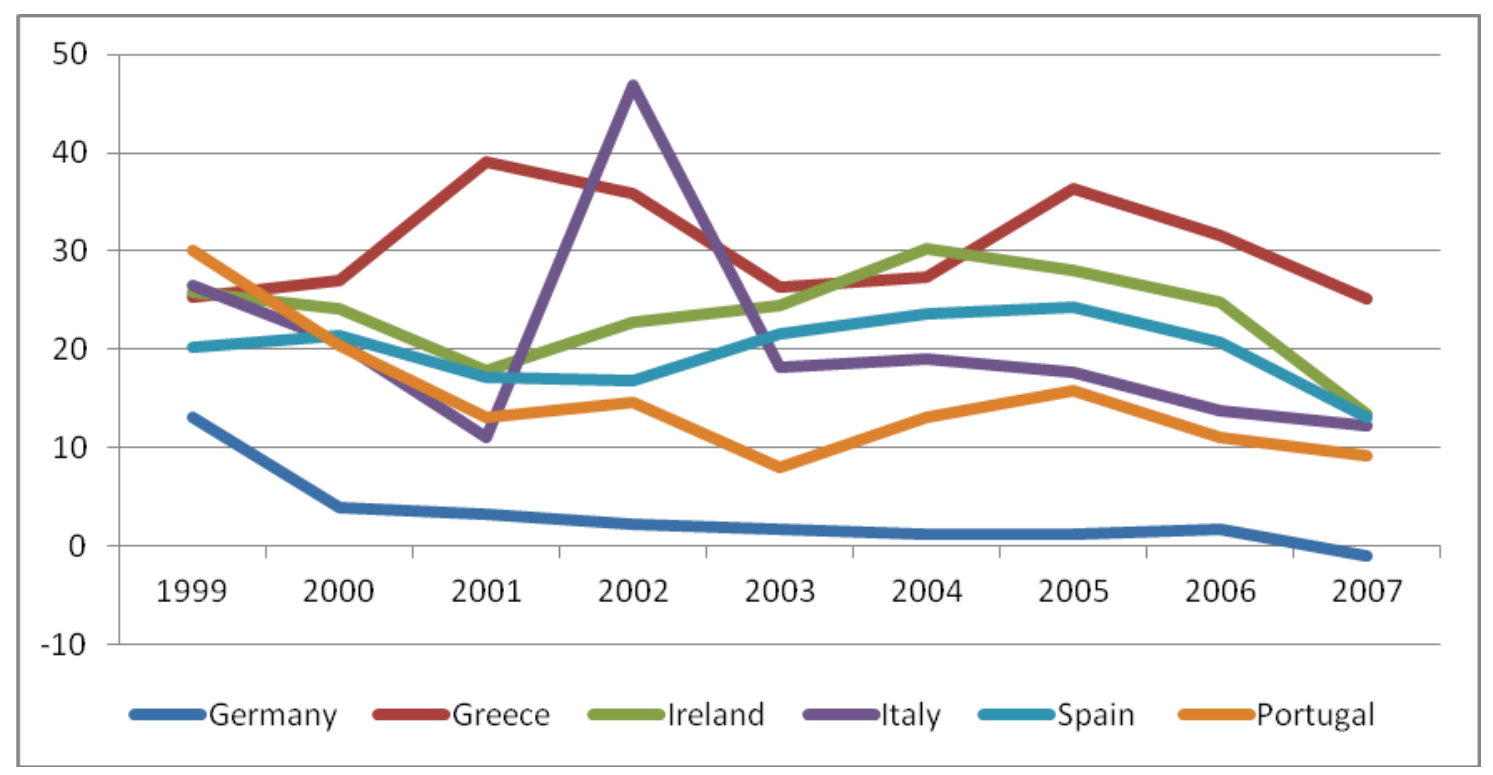

Source: ECB 2009

Further, according to the European Central Bank (2009), the growth rates of mortgage loans in the peripheral countries increased significantly; see Figure 6 above. Arguably, in certain countries of the periphery, a housing bubble - similar to the one in the United States - had developed with the process of financial deregulation.

Private debt accumulation (underpinned by financial liberalization which allowed finance to flow from core to noncore countries), in turn, contributed to underpinning internal aggregate demand growth and imports. Thus, the lending boom in the periphery allowed core countries to pursue a strategy of export-led growth.

The imbalances between a set of core countries growing at the expense of mounting disequilibria and debt accumulation in the noncore countries or periphery made them vulnerable to changing external conditions, as shown by the onset and impact of the Global Crisis (2007$2008)^{23}$

Unfortunately, due to the fact that in a time of crisis, governments must increase expenditure (even if only through automatic stabilizers) in order to mitigate its impact, while at the same time revenues tend to decline (due to output contraction or outright recession), budget

\footnotetext{
${ }^{23}$ Cesaratto and Stirati (2011) suggest that German mercantilism — that is, the stagnant wages and export-led strategy of growth in Germany-is at the center of the crisis. Our analysis suggests that export-led strategy was a feature of the ensemble of core countries.
} 
deficits are inevitable and emerge as a favorite cause of the crisis itself. As shown in Figure 7 below, public debt was relatively constant or decreasing in the case of both core and noncore countries, without exception, up to the 2007-2008 crisis. Only then did the levels of public debt increase at a significant rate. A similar conclusion emerges from the evidence presented on budget deficits in Table 7 above.

Figure 7 Public debt (\% GDP)

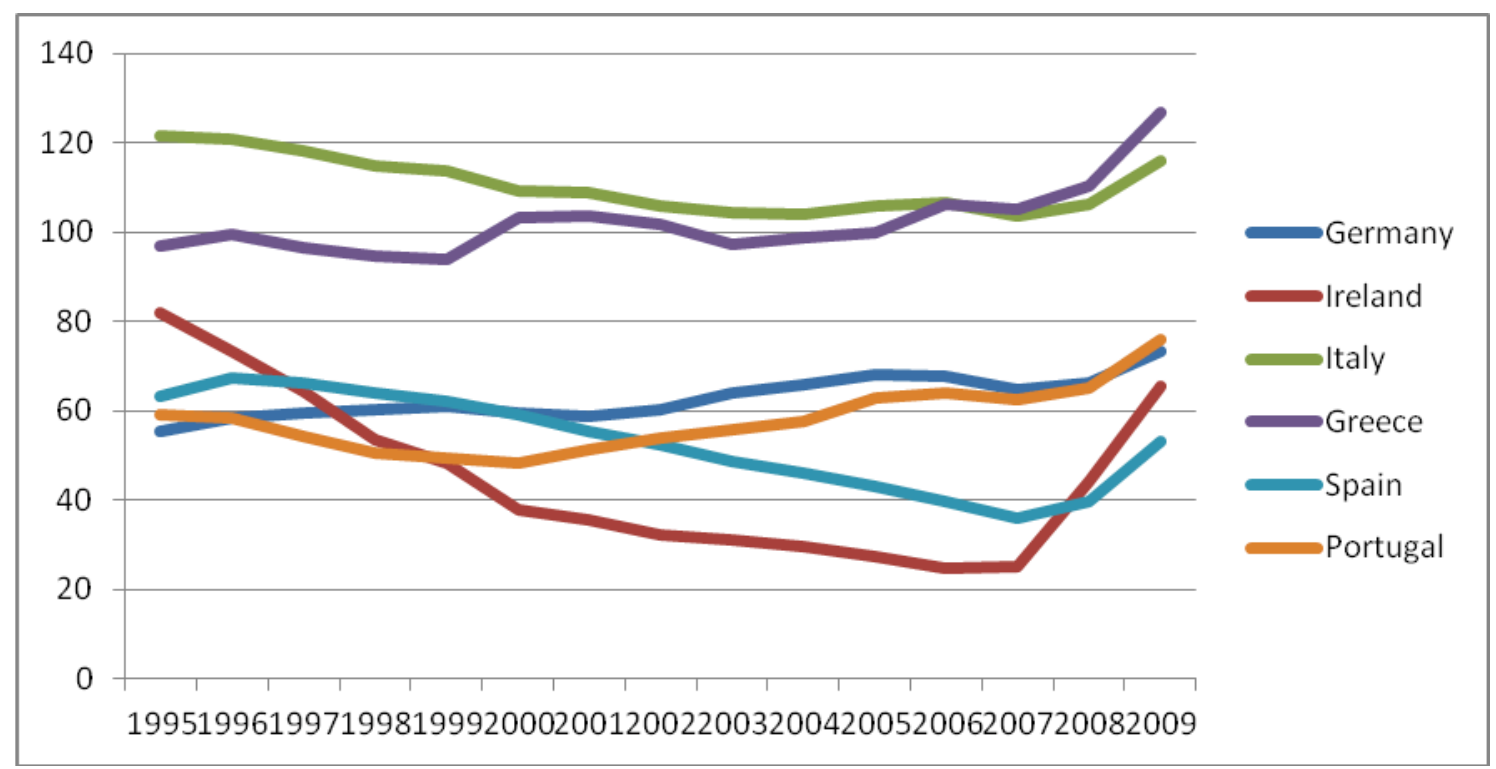

Source: Eurostat 2011 


\section{THE MYTHS AND FACTS OF POLICY}

These stylized macroeconomic facts of eurozone imbalances underscore that central to the different views of neoclassical and post-Keynesian authors (with respect to the European crisis) is the question of causality relating the fiscal and external crisis. From our post-Keynesian point of view, the evidence against a fiscal crisis is so clear-cut that it is somewhat perplexing that the academic and political debate is fundamentally about whether the SGP should be strengthened or a new arrangement should be implemented to promote fiscal centralization at the supranational level. Note that the effort for fiscal centralization is seen as a necessary step toward more stringent fiscal adjustment, and not as a step toward reducing the problems associated with the common currency, promoting fiscal transfers to distressed economies.

In fact, the IMF supported adjustment programs for three noncore countries; Greece, Ireland, and Portugal clearly accept the notion that fiscal consolidation and adjustment is essential - even in the face of a recession. Greece, Ireland, and Portugal were committed to reducing their respective budget deficits from an estimated 8 percent, 32 percent, and 9 percent in 2010, respectively, to a level below 3 percent in 2014. As well, the two other peripheral countries, Italy and Spain, also contemplate important reductions in their budget balances from -4.5 percent to -2.4 percent, and from -9.2 percent to -5.2 percent of GDP between 2010 and 2012, respectively; see Table 8 below. ${ }^{24}$

In the particular case of Greece, the public deficit turned out to be higher than the estimated 8 percent for 2010 (the actual deficit turned out to be 10.5 percent of GDP). Moreover, the government declared that it will not be able to meet its target reduction deficit for 2011 ( 8.5 percent of GDP). This has prompted well-founded fears of debt default and financial contagion throughout Europe and other parts of the world. More recently, doubts have also been cast over other noncore countries' abilities to comply with their fiscal targets.

\footnotetext{
${ }^{24}$ See IMF 2011a.
} 


\begin{tabular}{|c|c|c|c|}
\hline \multicolumn{4}{|c|}{$\begin{array}{c}\text { Table } 8 \\
\text { IMF supported adjustment programs }\end{array}$} \\
\hline Country & $\begin{array}{l}\text { Type and date of } \\
\text { program }\end{array}$ & $\begin{array}{l}\text { Size of } \\
\text { program }\end{array}$ & Main fiscal measures \\
\hline Greece & $\begin{array}{l}\text { Stand-by- } \\
\text { Arrangement (May } \\
\text { 2010) }\end{array}$ & $\begin{array}{l}\text { US\$ } 30 \\
\text { billion, or } \\
11 \% \text { of GDP }\end{array}$ & $\begin{array}{l}\text { Restore Fiscal sustainability. Lower the } \\
\text { overall deficit from } 8.1 \% \text { in } 2010 \text { to } \\
\text { below } 3 \% \text { of GDP by } 2014 \text { (with a } \\
\text { primary fiscal balance surplus). Fiscal } \\
\text { effort mainly through public sector } \\
\text { wage cuts to regain market access. } \\
\text { Place the debt-to-GDP ratio on a } \\
\text { declining trend. The consolidation } \\
\text { measures are estimated to be equivalent } \\
\text { to } 8 \% \text { of GDP. }\end{array}$ \\
\hline Ireland & $\begin{array}{l}\text { Extended Fund } \\
\text { Facility } \\
\text { (December 2010) }\end{array}$ & $\begin{array}{l}\text { US\$ } 30.1 \\
\text { billion }\end{array}$ & $\begin{array}{l}\text { Sizable fiscal adjustment to bring the } \\
\text { overall deficit from }-32 \% \text { of GDP to } \\
\text { below } 3 \% \text { of GDP by } 2015 \text {. The fiscal } \\
\text { adjustment focuses on significant } \\
\text { declines in public expenditure (wages } \\
\text { and employment) with some capital } \\
\text { expenditure cuts. The consolidation } \\
\text { measures are estimated to be equivalent } \\
\text { to } 9 \% \text { of GDP. }\end{array}$ \\
\hline Portugal & $\begin{array}{l}\text { Extended Fund } \\
\text { Facility } \\
\text { (May 2011) }\end{array}$ & $\begin{array}{l}\text { US\$ } 37.8 \\
\text { billion }\end{array}$ & $\begin{array}{l}\text { Reach a } 3 \% \text { of GDP deficit by } 2013 \\
\text { with stable debt to GDP ratios. The } \\
\text { deficit in } 2010 \text { was estimated at } 9.1 \% \\
\text { of GDP. The bulk of the adjustment is } \\
\text { placed on public current and capital } \\
\text { expenditure. The overall required fiscal } \\
\text { adjustment was estimated at } 10 \% \text { of } \\
\text { GDP. }\end{array}$ \\
\hline \multicolumn{4}{|c|}{$\begin{array}{l}\text { Note: In the year the IMF programs were approved, the overall fiscal balances for Greece, Ireland, and } \\
\text { Portugal were -10.4 percent, - } 32 \text { percent and -9.1 percent, respectively. } \\
\text { Sources: Based on Regional Economic Outlook, IMF } 2011 \text { b; Press Release No. 10/187, } \\
\text { IMF 2010a; Press Release No. 10/496, IMF 2010b; Country Report No. 11/127: Portugal, IMF 2011c; } \\
\text { "Greece: Letter of Intent, IMF 2010c; "Ireland: Letter of Intent, IMF 2010d" }\end{array}$} \\
\hline
\end{tabular}

The contractionary fiscal stance and the slack in private demand implies that recovery is expected to come from the external sector. As shown in Table 7 above, private sector balances of both core and noncore countries began to be in surplus following the Global Crisis. However, in a context such as that of the European Union where the bulk of trade is intraregional, and in a situation of stagnant internal demand - in particular, in noncore countries - external sector-led recovery can only imply an expectation that low wages and deflation will do the work of increasing external competitiveness. This is, from our point of 
view, a self-defeating strategy — as it comes at high costs in terms of unemployment, and will contract aggregate demand even further.

Annual unemployment rate in the eurozone averaged above 8 percent in the period 20012007, increasing to 10 percent following the Global Crisis. In the noncore countries, the postcrisis unemployment rate was almost twice that of the pre-crisis period (7.8 percent and 14 percent respectively; see Table 9 below).

\begin{tabular}{|c|c|c|c|c|c|c|}
\hline \multicolumn{7}{|c|}{$\begin{array}{c}\text { Table } 9 \\
\text { Eurozone }\end{array}$} \\
& $\begin{array}{c}\text { Annual Unemployment Rates } \\
\text { 2001-2012 (in percentage) }\end{array}$ \\
\hline & 2001 & $2002-2007$ & $2008-2009$ & 2010 & 2011 & 2012 \\
\hline Euro area & 8.1 & 8.6 & 8.6 & 10.1 & 10.0 & 9.9 \\
\hline Belgium & 6.6 & 8.1 & 7.5 & 8.3 & 7.4 & 7.2 \\
\hline Germany & 7.6 & 9.6 & 7.7 & 7.1 & 6.1 & 5.9 \\
\hline France & 8.3 & 9.0 & 8.7 & 9.8 & 9.6 & 9.3 \\
\hline Netherlands & 2.5 & 4.3 & 3.4 & 4.5 & 4.4 & 4.8 \\
\hline Austria & 3.6 & 4.6 & 4.3 & 4.4 & 4.2 & 4.3 \\
\hline Ireland & 3.9 & 4.5 & 9.1 & 13.7 & 14.5 & 14.3 \\
\hline Greece & 10.7 & 9.6 & 8.6 & 12.6 & 15.7 & 15.9 \\
\hline Spain & 10.3 & 9.8 & 14.7 & 20.1 & 21.0 & 21.1 \\
\hline Portugal & 4.6 & 7.7 & 9.6 & 12.0 & 12.7 & 13.5 \\
\hline Italy & 9.1 & 7.6 & 7.3 & 8.4 & 8.1 & 8.2 \\
\hline Core Countries & 5.7 & 7.1 & 6.3 & 6.8 & 6.3 & 6.3 \\
\hline Noncore countries & 7.7 & 7.9 & 9.8 & 13.4 & 14.4 & 14.6 \\
\hline Unemployment rate & & & & & & \\
differential (in percentage & & & & & & \\
points) & 2.0 & 0.7 & 3.5 & 6.5 & 8.1 & 8.3 \\
\hline Sources: Eurostat 2011; Ernst and Young 2011 & & & & & \\
\hline
\end{tabular}

These developments do not bode well for the future of the European recovery, for the euro, and consequently for the world economy - which will be negatively impacted by a sluggish recovery in Europe. According to our own estimates, based on an optimistic outlook, the rate of growth of GDP per capita in the core countries will be close to 1 percent in 2012, while in noncore countries it will contract to below -1.5 percent on average.

As noted in our discussion, it seems that the evidence does not support the conventional wisdom; according to which, the European crisis has been fiscal in nature. Even in the case of Greece, which encountered more fiscal problems in the years preceding the crisis, interest rates converged, and the fiscal imbalances only increased after 2007. From our point of view, the 
crisis is emblematic of internal imbalances between core and noncore countries under financial deregulation that did not prove to be sustainable over time.

Imbalances in a Monetary or Currency Union are bound to occur when its state members are economically heterogeneous and different. Recognition of this fact requires that the establishing Union must create, as part of its constituent, charter mechanisms to solve and clear the imbalances - rather than making them cumulative over time, as in the case of the eurozone. More than half a century ago, John Maynard Keynes (1980 [1941]) devised an important principle in the design of his proposal for a Clearing Union, which is relevant to the European case. This principle is the "generalization of the essential principle of banking;" namely, the "equality of credits and debits, of assets and liabilities" (Keynes 1980 [1941], p.44). In practice, this amounted to the recycling of balances from surplus to deficit countries to maintain the dynamics of aggregate demand. This implies that the creditor country should play an active role as part of an equilibrating mechanism, and that the brunt of the adjustment should not be borne by the debtor country, which happens to be the weaker and less developed country.

Placing an equilibrating principle at the center of monetary integration would help to produce a rebalancing of external accounts, increase the policy space for fiscal expansion, and undertake economic growth and full-employment policies. As important in the current juncture, it would preempt to a great extent the need to design and implement rescue package funds, such as the Financial Stability Facility or for the European Central Bank to bail out governments through the purchase of government bonds. ${ }^{25}$ In a similar manner, the survival of the eurozone would not be as dependent as it currently is on commercial bank recapitalization or nationalization. ${ }^{26}$

\footnotetext{
${ }^{25}$ The Financial Stability Facility (EFSF) was created in May 2010. It provides (in conjunction with the IMF) financial assistance to euro country member states with guarantees of up to 440 billion euros-which has been recently enlarged to 780 billion euros. The EFSF is a funding mechanism through bond issues backed by the more developed European economies. The authority to spend the money is left to the governments of member states; see Soros 2011. The Financial Stability Facility (EFSF) will be replaced in 2013 by the European Stability Mechanism. Since May 2010, the purchase of bonds by the European Central Bank amounts to 156,500 million euros.

${ }^{26}$ The current level of capitalization is 5 percent. A proposal has been tabled to increase it to 9 percent. The recent credit downgrading of noncore countries has increased the pressure to recapitalize banks (and obviously the push for fiscal consolidation).
} 


\section{REFERENCES}

Allen, Franklin, Thorsten Beck, Elena Carletti, Philip R. Lane, Dirk Schoenmaker, and Wolf Wagner. 2011. "Cross-Border Banking in Europe: Implications for Financial Stability and Macroeconomic Policies." Centre for Economic Policy Research (CEPR): London, UK.

Beck, Thorsten and Asli Demirgüç-Kunt. 2009. "Financial Institutions and Markets Across Countries and over Time: Data and Analysis." World Bank Policy Research Working Paper No. 4943, May 2009.

Bank for International Settlements. 2005. "Financial Deregulation in the EU -Chances and Challenges for Financial Stability." Speech by Dr. Klaus Liebscher, Governor of the Austrian National Bank to the $5^{\text {th }}$ Annual CSI Conference, "New Agenda of the WTO: Challenge and Contribution of the European Union." Innsbruck, Austria: November 18, 2005.

- 2011. Table 2A: External Positions of Banks in All Currencies Vis-à-Vis All Sectors. http://www.bis.org/publ/qtrpdf/r_qa1112_anx2a.pdf (accessed on December 19, 2011).

Bortis, H. 1997. Institutions, Behaviour and Economic Theory. Cambridge, UK: Cambridge University Press.

Buch, C. \& Heinrich, R.P. 2002. "Financial Integration in Europe and Banking Sector Performance." Kiel Institute of World Economics. Paper written for the project "The Benefits of a Working EU Market in Financial Services.” Kiel, Germany: January 2002.

Burnside, C., M. Eichenbaum, and S. Rebelo. 2007. "Currency Crisis Models." In S. Durlauf and L. Blume (eds.) The New Palgrave: A Dictionary of Economics, $2^{\text {nd }}$ Edition. Palgrave/Macmillan.

Chinn, Menzie D. and Hiro Ito. 2008. “A New Measure of Financial Openness.” Journal of Comparative Policy Analysis 10(3):309-322

Calvo, G. 1988. "Servicing the Public Debt: The Role of Expectations." American Economic Review 78(4):647-61.

Cesaratto, S. and Stirati, A. 2011. "Germany and the European and Global Crises." International Journal of Political Economy 39(4):56-87.

De Grauwe, P. 2003. Economics of Monetary Union. Oxford University Press: New York.

Ernst \& Young. 2011. Eurozone Forecast: Autumn Edition. September 2011.

European Central Bank (ECB). 2011. Statistics. http://www.ecb.int/stats/html/index.en.html (accessed on December 19, 2011). 
European Commission. 2005-2010. Financial Services Policy White Paper. Brussels, Belgium, January 12, 2005.

- 2011. Transportation of Financial Services Action Plan (FSAP) Directives and PostFSAP Directives.

http://ec.Europa.eu/internal_market/finances/actionplan/index_en.htm\#transposition. (accessed December 19, 2011).

- 2011b. Employment and Unemployment (LFS): Database.

http://epp.eurostat.ec.europa.eu/portal/page/portal/employment unemployment lfs/data/ database (accessed December 19, 2011).

European Council. 1992a. The Maastricht Treaty-Provisions Amending the Treaty Establishing the European Economic Community With a View to Establishing the European Community. Maastricht, Netherlands. http://www.Eurotreaties.com/maastrichtec.pdf (accessed on December 19, 2011).

. 1992b. The Maastricht Treaty-Treaty on European Union and the Treaties Establishing the European Communities: Protocols. Maastricht, Netherlands.

http://www.Eurotreaties.com/maastrichtprotocols.pdf (accessed on December 19, 2011).

Eurostat. 2011. Statistics by Theme.

http://epp.eurostat.ec.europa.eu/portal/page/portal/statistics/themes (accessed on December 19, 2011).

Ford, A. G. (1962), The Gold Standard, 1880-1914: Britain and Argentina, New York: Oxford University Press.

IMF. 2010a. Press Release No. 10/187. IMF: Washington, D.C. May 9, 2010. http://www.imf.org/external/np/sec/pr/2010/pr10187.htm (accessed December 19, 2011).

- 2010b. Press Release No. 10/496. IMF: Washington, D.C. December 16, 2010. http://www.imf.org/external/np/sec/pr/2010/pr10496.htm (accessed December 19, 2011).

_. 2010c. “Greece: Letter of Intent.” IMF: Washington, D.C. August 6, 2010. http://www.imf.org/external/np/loi/2010/grc/080610.pdf (accessed on December 20, 2011).

_ 2010d. "Ireland: Letter of Intent," IMF: Washington, D.C. December 3, 2010. http://www.imf.org/external/np/loi/2010/irl/120310.pdf (accessed on December 20, 2011).

- 2011a. Fiscal Monitor: Addressing Fiscal Challenges to Reduce Economic Risks. IMF: Washington, D.C. September 2011.

. 2011b. Regional Economic Outlook: Europe. Navigating Stormy Waters. IMF: Washington, D.C. October 2011. 
- 2011c. Country Report No. 11/127: Portugal. IMF: Washington, D.C. June 2011. http://www.imf.org/external/pubs/ft/scr/2011/cr11127.pdf (accessed December 19, 2011).

Kalemli-Ozcan, Sebnem, Elias Papaioannou, and José-Luis Peydró. 2010. "What Lies Beneath the Euro's Effect on Financial Integration: Currency Risk, Legal Harmonization, or Trade?” European Central Bank. Working Paper Series. No 1216, June 2010.

Kenen, P.B. 1995. Economic and Monetary Union in Europe. Cambridge University Press: New York.

Keynes, John Maynard. 1980. Collected Writings, Vol. XXV, Activities 1940-1944, Shaping the Post-War World: The Clearing Union. Editor Donald Moggridge. London, UK: Macmillan, Cambridge University Press.

Krugman, P. 1979. “A model of balance of payments crises” Journal of Money, Credit, and Banking 11:311-25.

- 1999. "Balance Sheets, the Transfer Problem, and Financial Crises." International Tax and Public Finance 6:459-72.

McCombie, J. and A. P. Thirlwall. 1994. Economic Growth and the Balance of Payments Constraint. London, UK: Macmillan.

Papadimitriou D. and R. Wray. 2011. "Euroland in Crisis as the Global Meltdown Picks Up Speed.” Working Paper No. 693. Annandale-On-Hudson, NY: Levy Economics Institute of Bard College.

Pérez-Caldentey, E. \& Matías Vernengo. 2010. "How Stimulative Has Fiscal Policy Been Around the World?" Challenge (http://ideas.repec.org/s/mes/challe.html). M.E. Sharpe, Inc. 53(3):6-31, May. http://ideas.repec.org/a/mes/challe/v53y2010i3p6-31.html (accessed on December 20, 2011).

Soros, G. 2010. "The Crisis and the Euro.” The New York Review of Books. July 12, 2010. http://www.georgesoros.com/articles-essays/entry/the crisis and the Euro/ (accessed on December 19, 2011).

- 2011. "Does the Euro Have a Future?" The New York Review of Books. October 13, 2011. http://www.georgesoros.com/articles-essays/entry/does_the_euro_have_a_future/ (accessed on December 19, 2011).

Wyplosz, C. 2010. "Eurozone Reform: Not Yet Fiscal Discipline, But a Good Start," Vox.eu. October 10, 2010. http://www.voxeu.org/index.php?q=node/5610 (accessed on December 20, 2011).

World Bank. 2011. Global Development Indicators and Global Finance. Washington, D.C.: World Bank Group. 
WITS (2011) World Integrated Trade Solution. World Bank. http://wits.worldbank.org/wits/ (accessed on December 19, 2011).

Zarco, Ismael A. 2009. "Financial Assets and Liabilities of Households in the European Union." Economy and Finance, Eurostat: Statistics in Focus. 32/2009. http://epp.eurostat.ec.europa.eu/cache/ITY OFFPUB/KS-SF-09-032/EN/KS-SF-09-032EN.PDF (accessed on December 20, 2011). 


\section{APPENDIX}

\begin{tabular}{|c|c|c|c|c|c|c|c|c|c|c|c|c|}
\hline \multicolumn{13}{|c|}{$\begin{array}{c}\text { Table } 10 \\
\text { Unit labor costs for core and noncore countries } \\
2000-2010(2000=100)\end{array}$} \\
\hline & Austria & Belgium & France & Germany & Netherlands & Greece & Ireland & Italy & Spain & $\begin{array}{l}\text { Average } \\
\text { Noncore } \\
\text { countries }\end{array}$ & $\begin{array}{l}\text { Average } \\
\text { Core } \\
\text { countries }\end{array}$ & $\begin{array}{l}\text { Ratio of NC } \\
\text { to Core }\end{array}$ \\
\hline 2000 & 100 & 100 & 100 & 100 & 100 & 100 & 100 & 100 & 100 & 100 & 100 & 1.00 \\
\hline 2001 & 101.0 & 103.7 & 102.3 & 100.4 & 104.7 & 100.0 & 103.8 & 103.3 & 103.1 & 102.5 & 102.4 & 1.00 \\
\hline 2002 & 101.3 & 106.3 & 105.2 & 100.8 & 109.3 & 109.1 & 103.9 & 106.8 & 106.2 & 106.5 & 104.6 & 1.02 \\
\hline 2003 & 102.4 & 107.1 & 107.2 & 101.5 & 111.8 & 110.4 & 108.8 & 111.5 & 109.6 & 110.1 & 106.0 & 1.04 \\
\hline 2004 & 101.8 & 107.1 & 108.2 & 100.6 & 112.2 & 111.8 & 112.4 & 113.2 & 112.3 & 112.4 & 106.0 & 1.06 \\
\hline 2005 & 103.0 & 108.7 & 110.2 & 99.7 & 111.8 & 115.8 & 119.1 & 116.6 & 116.1 & 116.9 & 106.7 & 1.10 \\
\hline 2006 & 103.5 & 110.8 & 112.4 & 97.8 & 112.6 & 119.2 & 124.0 & 118.7 & 119.8 & 120.4 & 107.4 & 1.12 \\
\hline 2007 & 104.0 & 113.2 & 113.8 & 97.2 & 114.5 & 123.7 & 128.0 & 121.3 & 124.3 & 124.3 & 108.5 & 1.15 \\
\hline 2008 & 106.1 & 117.8 & 116.6 & 99.5 & 117.3 & 130.4 & 133.6 & 126.2 & 130.1 & 130.1 & 111.5 & 1.17 \\
\hline 2009 & 111.6 & 123.0 & 119.8 & 105.8 & 123.5 & 136.6 & 128.8 & 131.5 & 131.1 & 132.0 & 116.7 & 1.13 \\
\hline 2010 & 111.8 & 122.6 & 120.7 & 104.0 & 121.9 & 135.8 & 121.8 & 131.2 & 129.3 & 129.5 & 116.2 & 1.11 \\
\hline
\end{tabular}




\begin{tabular}{|c|c|c|c|c|c|c|c|c|c|c|}
\hline \multicolumn{11}{|c|}{$\begin{array}{c}\text { Table } 11 \\
\text { Financial balances of core and noncore European countries as a share of GDP } \\
2001-2010\end{array}$} \\
\hline & 2001 & 2002 & 2003 & 2004 & 2005 & 2006 & 2007 & 2008 & 2009 & 2010 \\
\hline \multicolumn{11}{|c|}{ Current Account Balance } \\
\hline France & 1.8 & 1.2 & 0.7 & 0.5 & -0.5 & -0.6 & -1.0 & -1.8 & -1.5 & -1.7 \\
\hline Germany & 0.0 & 2.0 & 1.9 & 4.7 & 5.0 & 6.3 & 7.5 & 6.3 & 5.7 & 5.7 \\
\hline Belgium & & 4.6 & 3.5 & 3.2 & 2.0 & 1.9 & 1.5 & -1.6 & 0.4 & 1.0 \\
\hline Austria & -0.8 & 2.7 & 1.7 & 2.1 & 2.1 & 2.4 & 3.5 & 4.9 & 2.9 & 2.8 \\
\hline Netherlands & 2.4 & 2.5 & 5.5 & 7.6 & 7.3 & 9.3 & 6.7 & 4.5 & 4.9 & 7.2 \\
\hline Greece & -7.2 & -6.5 & -6.6 & -5.9 & -7.5 & -11.2 & -14.3 & -14.8 & -11.0 & -10.6 \\
\hline Italy & -0.1 & -0.8 & -1.3 & -1.0 & -1.7 & -2.6 & -2.4 & -2.9 & -1.9 & -3.5 \\
\hline Portugal & -10.3 & -8.2 & -6.5 & -8.4 & -10.4 & -10.7 & -10.1 & -12.6 & -10.9 & -9.9 \\
\hline Spain & -4.0 & -3.2 & -3.5 & -5.3 & -7.4 & -9.0 & -10.0 & -9.7 & -5.1 & -4.6 \\
\hline Ireland & -0.7 & -0.9 & 0.1 & -0.6 & -3.5 & -3.5 & -5.3 & -5.8 & -2.8 & 0.5 \\
\hline Average Core Countries & 0.9 & 2.6 & 2.7 & 3.6 & 3.2 & 3.9 & 3.6 & 2.5 & 2.5 & 3.0 \\
\hline Average Noncore Countries & -4.4 & -3.9 & -3.6 & -4.2 & -6.1 & -7.4 & -8.5 & -9.2 & -6.4 & -5.6 \\
\hline \multicolumn{11}{|c|}{ Fiscal Balance } \\
\hline France & -1.5 & -3.1 & -4.1 & -3.6 & -2.9 & -2.3 & -2.7 & -3.3 & -7.5 & -7.0 \\
\hline Germany & -2.8 & -3.7 & -4.0 & -3.8 & -3.3 & -1.6 & 0.3 & 0.1 & -3.0 & -3.3 \\
\hline Belgium & 0.4 & -0.1 & -0.1 & -0.3 & -2.7 & 0.1 & -0.3 & -1.3 & -5.9 & -4.1 \\
\hline \multicolumn{11}{|l|}{ Austria } \\
\hline Netherlands & -0.2 & -2.1 & -3.1 & -1.7 & -0.3 & 0.5 & 0.2 & 0.6 & -5.5 & -5.4 \\
\hline Greece & -4.5 & -4.8 & -5.6 & -7.5 & -5.2 & -5.7 & -6.4 & -9.8 & -15.4 & -10.5 \\
\hline Italy & -3.1 & -2.9 & -3.5 & -3.5 & -4.3 & -3.4 & -1.5 & -2.7 & -5.4 & -4.6 \\
\hline Portugal & -4.3 & -2.9 & -3.0 & -3.4 & -5.9 & -4.1 & -3.1 & -3.5 & -10.1 & -9.1 \\
\hline Spain & -0.6 & -0.5 & -0.2 & -0.3 & 1.0 & 2.0 & 1.9 & -4.2 & -11.1 & -9.2 \\
\hline Ireland & 0.9 & -0.4 & 0.4 & 1.4 & 1.6 & 2.9 & 0.1 & -7.3 & -14.3 & -32.4 \\
\hline Average Core Countries & -1.0 & -2.3 & -2.8 & -2.4 & -2.3 & -0.8 & -0.6 & -1.0 & -5.5 & -5.0 \\
\hline Average Noncore Countries & -2.3 & -2.3 & -2.4 & -2.7 & -2.6 & -1.7 & -1.8 & -5.5 & -11.3 & -13.2 \\
\hline
\end{tabular}


Private Sector Balance

\begin{tabular}{|c|c|c|c|c|c|c|c|c|c|c|}
\hline & & & & & & & & & & \\
\hline France & 3.3 & 4.3 & 4.8 & 4.1 & 2.4 & 1.7 & 1.7 & 1.5 & 6.0 & 5.3 \\
\hline Germany & 2.8 & 5.7 & 5.9 & 8.5 & 8.3 & 7.9 & 7.2 & 6.2 & 8.7 & 9.0 \\
\hline Belgium & -0.4 & 4.7 & 3.6 & 3.5 & 4.7 & 1.8 & 1.8 & -0.3 & 6.3 & 5.1 \\
\hline Austria & -0.8 & 2.7 & 1.7 & 2.1 & 2.1 & 2.4 & 3.5 & 4.9 & 2.9 & 2.8 \\
\hline Netherlands & 2.6 & 4.6 & 8.6 & 9.3 & 7.6 & 8.8 & 6.5 & 3.9 & 10.4 & 12.6 \\
\hline Greece & -2.7 & -1.7 & -1.0 & 1.6 & -2.3 & -5.5 & -7.9 & -5.0 & 4.4 & -0.1 \\
\hline Italy & 3.0 & 2.1 & 2.2 & 2.5 & 2.6 & 0.8 & -0.9 & -0.2 & 3.5 & 1.1 \\
\hline Portugal & -6.0 & -5.3 & -3.5 & -5.0 & -4.5 & -6.6 & -7.0 & -9.1 & -0.8 & -0.8 \\
\hline Spain & -3.4 & -2.7 & -3.3 & -5.0 & -8.4 & -11.0 & -11.9 & -5.5 & 6.0 & 4.6 \\
\hline Ireland & -1.6 & -0.5 & -0.3 & -2.0 & -5.1 & -6.4 & -5.4 & 1.5 & 11.5 & 32.9 \\
\hline Average Core Countries & 1.5 & 4.4 & 4.9 & 5.5 & 5.0 & 4.5 & 4.1 & 3.2 & 6.8 & 6.9 \\
\hline Average Noncore Countries & -2.1 & -1.6 & -1.2 & -1.5 & -3.5 & -5.7 & -6.7 & -3.7 & 4.9 & 7.5 \\
\hline
\end{tabular}

